\section{University of New Hampshire}

Carsey School of Public Policy

\section{CARSEY RESEARCH}

Regional Issue Brief \#49

Spring 2017

\title{
The Zika Virus Threat
}

\section{How Concerns About Scientists May Undermine Efforts to Combat the Pandemic}

\author{
Thomas G. Safford, Lawrence C. Hamilton, and Emily H. Whitmore
}

\section{Introduction}

Shocking images of infants with severe birth defects in Brazil introduced the world to the devastating effects of the Zika virus. This mosquito-borne illness spread rapidly across Latin America and into the United States. News stories highlighting locally transmitted cases of Zika in Florida, and most recently in Texas, created a sense of urgency among public health officials. They stepped up efforts to inform the public about the transmission of the virus as well as the health risks associated with Zika. Public polling shows that Americans are becoming increasingly concerned about the threat of Zika, and they question the government's ability to limit its spread. ${ }^{1}$ What is less clear are the factors influencing perceptions of the Zika pandemic and support for governmental efforts to curb the spread of the virus.

Using data from the October 2016 Granite State Poll (GSP), we investigate how New Hampshire residents view the Zika crisis by asking the following questions: Is Zika perceived as a threat to public health in the United States? Does the public trust the Centers for Disease Control and Prevention (CDC) for information about the virus? Is the public confident that the government can control the spread of Zika? Should the U.S. Congress prioritize emergency funding to combat Zika? Finally, we explore whether the public's increasing distrust of science and scientists may affect views about the Zika pandemic.

Results indicate that most New Hampshire residents believe Zika is only a minor threat to public health in the United States, and they generally trust the CDC as a source of information about the virus. These data also show that, while there is doubt about the government's ability to control the spread of the virus, the public feels that emergency federal funding

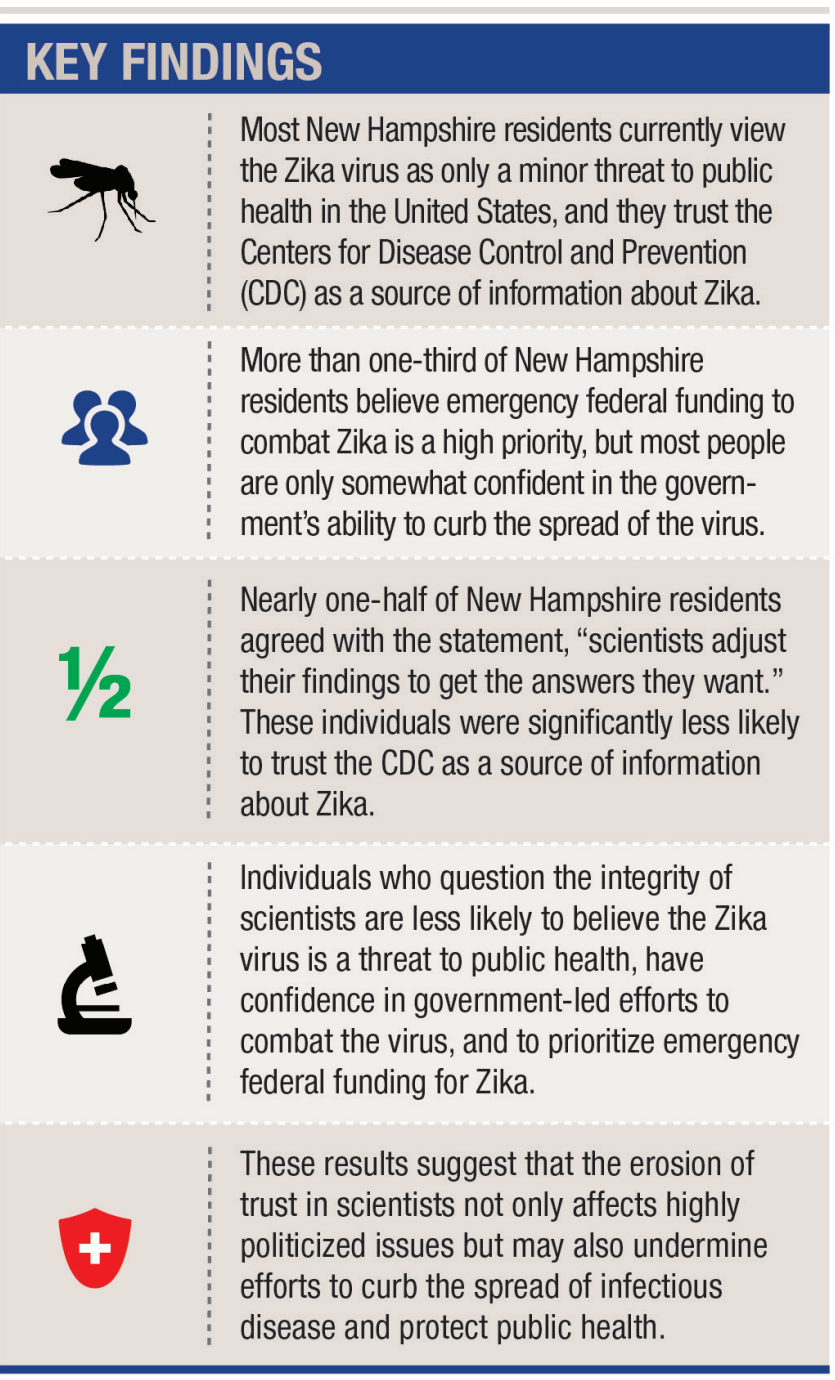

to combat Zika should be a priority. Finally, we found that many Granite Staters have real concerns about the practice of science, believing scientists change their findings to get the answers they want. More importantly, individuals who questioned the integrity 
of scientists are less likely to believe Zika is a threat, have confidence in the government's ability to combat the virus, trust the CDC, and to prioritize emergency funding. These results suggest that health officials working to engage the public in efforts to control the spread of Zika must not only discuss risks associated with the virus and mechanisms of transmission, but also confront science skepticism and potential concerns about the integrity of the scientists gathering data related to Zika and other infectious diseases.

\section{Zika Virus: An Evolving Public Health Emergency}

According to Dr. Anthony Fauci, director of the National Institute of Allergy and Infectious Disease at the National Institutes of Health, the pandemic expansion of Zika has created an urgent need for expanded research and new public health strategies to control the spread of the virus. ${ }^{2}$ The CDC has identified Zika as a serious public health threat to the United States and has made fighting Zika one of the agency's top priorities. $^{3}$ As of February 22, 2017, there have been 5,041 reported cases of Zika in the United States and an additional 37,447 in the U.S. territories of Puerto Rico, the U.S. Virgin Islands, and American Samoa. ${ }^{4}$ Initially, instances of Zika in the United States resulted from travel to and from impacted areas of Latin America and the Caribbean. However, the vast majority of the nearly 43,000 cases in the United States and the U.S. territories today are presumed to have been acquired through local mosquito-borne transmission. While the disease continues to pose the greatest threat to the southern United States, there have been 12 cases in New Hampshire and 121 in neighboring Massachusetts. ${ }^{5}$ All of these instances in New England are associated with travel to infected areas. Nonetheless, there is growing concern about the sexual transmission of the Zika virus and the likelihood of more locally transmitted cases across the United States in the warmer summer months of $2017 .{ }^{6}$

\section{Uncertainty About the Zika Virus Threat}

Given this national urgency, we investigated how New Hampshire residents view the threat of Zika and government-led efforts to combat the virus. Our data come from the October 2016 Granite State Poll (GSP), a quarterly public opinion poll of New Hampshire residents conducted by the University of New Hampshire Survey Center. ${ }^{7}$ Probability weights were used in our analyses to adjust for known sampling bias for telephone surveys and to make results more representative of the New Hampshire adult population. Three questions on the GSP queried respondents on their views about Zika and the government's efforts to fight it. Respondents were first asked whether they thought the spread of the Zika virus over the next few years will present a major threat, a minor threat, or not a threat at all to public health in the United States. ${ }^{8}$ While more than two-thirds of respondents viewed Zika as a threat, only 21 percent felt it was a major one (Figure 1). This result is logical given the small number of Zika cases in New Hampshire and the fact that non-travel related transmission has primarily occurred in Florida and the U.S. Caribbean Territories and not in New England.

\section{FIGURE 1. WILL ZIKA OVER THE NEXT FEW YEARS POSE A THREAT TO PUBLIC HEALTH IN THE UNITED STATES?}

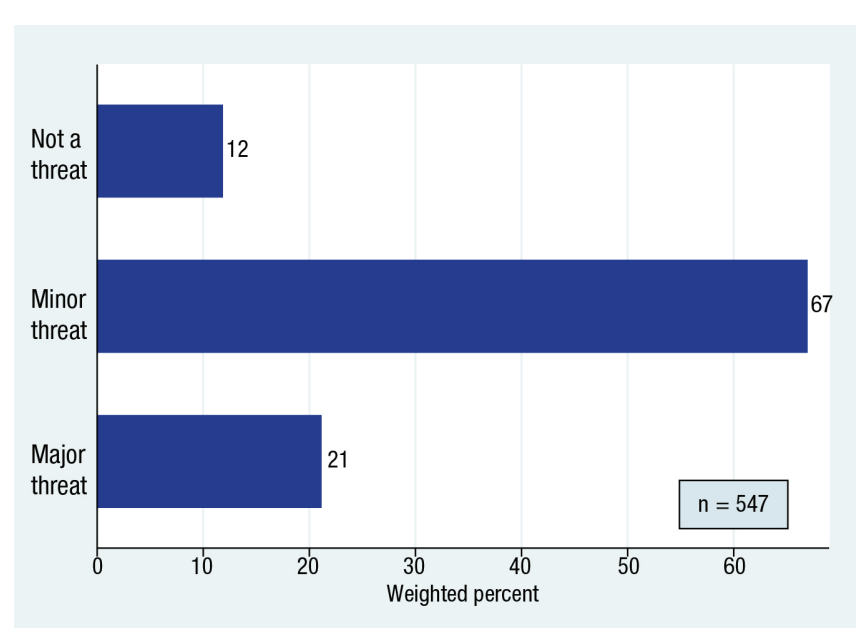

Source: October 2016 Granite State Poll

In the United States, the CDC has led efforts to understand and curb the spread of Zika, and the agency is the primary source of information about the transmission of the virus and the health risks associated with it. GSP respondents were asked whether they trust or don't trust the CDC as a source of information about the Zika virus. ${ }^{9}$ Poll results show a relatively high level of confidence, with 67 percent of respondents stating they trust the agency in this regard (Figure 2).

The fact that most individuals trust information disseminated by the CDC is encouraging for those working to inform the public about the risks associated with the Zika virus. However, our results show that New Hampshire residents are nevertheless uncertain about the federal government's ability to combat the pandemic. When 


\section{FIGURE 2. DO YOU TRUST THE CDC AS A SOURCE OF ZIKA INFORMATION?}

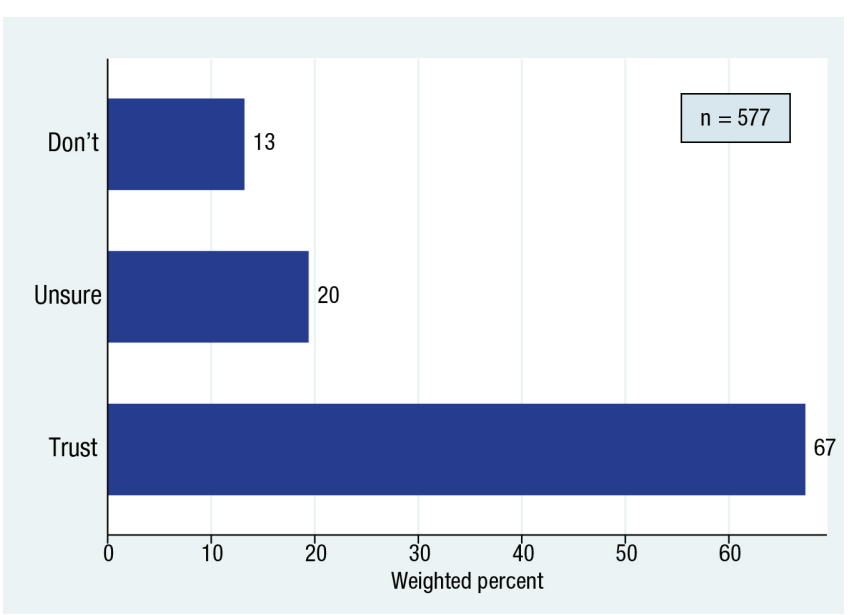

Source: October 2016 Granite State Poll

asked about their confidence in the government's ability to respond to an outbreak of Zika in the United States, 32 percent said they were either not very confident or not at all confident in the government's ability (Figure 3). ${ }^{10}$

\section{FIGURE 3. HOW CONFIDENT ARE YOU IN THE FEDERAL GOVERNMENT'S ABILITY TO RESPOND TO ZIKA?}

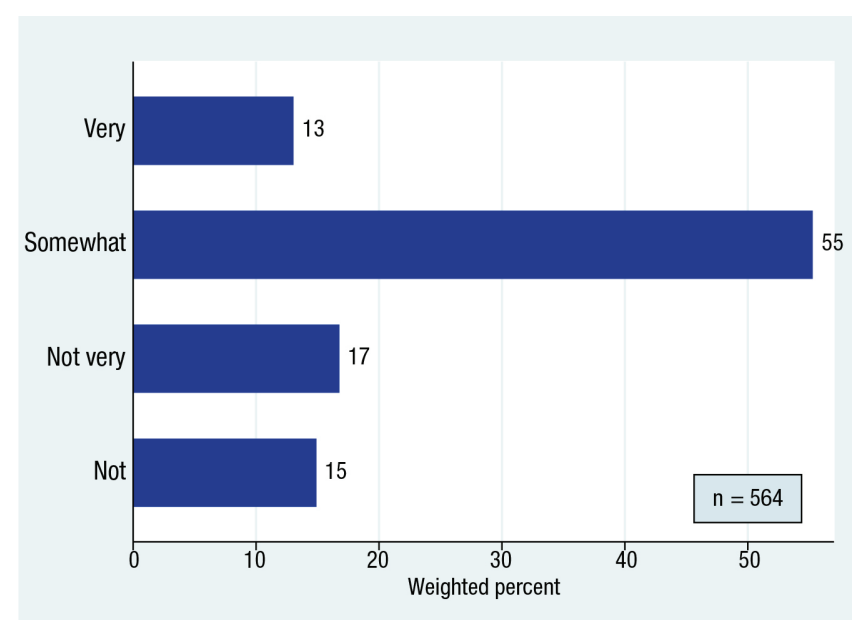

Source: October 2016 Granite State Poll

Finally, while U.S. public health officials identified Zika as a national health emergency in early 2016, the U.S. Congress did not approve special funding to combat the virus until the end of September. ${ }^{11}$ Data from the GSP show that Granite Staters see emergency funding for Zika as important, with 76 percent stating that it is a high or medium priority that Congress pass this emergency measure (Figure 4$)^{12}$

\section{FIGURE 4. HOW MUCH OF A PRIORITY IS EMERGENCY FUNDING TO COMBAT ZIKA?}

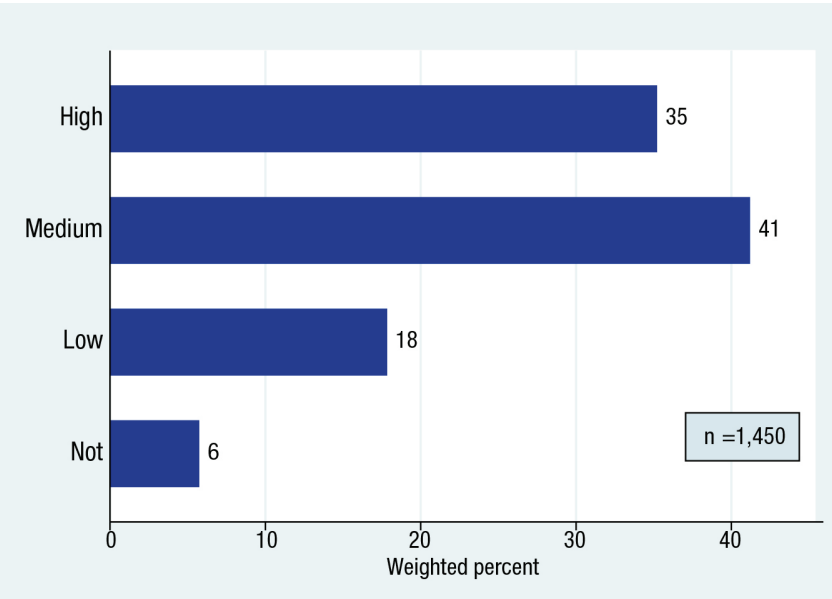

Source: October 2016 Granite State Poll

\section{The Integrity of Scientists and Beliefs About Zika}

Establishing whether New Hampshire residents are concerned about the Zika virus and are confident in the government's ability to respond to the pandemic is important. We also sought to investigate what factors might shape these beliefs and, in particular, whether the public's increasing skepticism about science might be influencing views about Zika. Previous research has found wide variations in public perceptions about scientists. ${ }^{13}$ One question on the GSP asked respondents whether they believed that scientists adjust their findings to get the answers they want. ${ }^{14}$ Poll results show that 43 percent of New Hampshire residents either agreed or strongly agreed with this statement (Figure 5). The fact that such a high percentage of individuals believe scientists manipulate their findings raises serious questions about the scientific community's ability to garner the public's trust and inform people about issues grounded in scientific findings.

Given that scientific information underpins virtually all communication about the Zika virus, we examined whether concern about the integrity of scientists, along with other social factors, influenced individual views about the Zika pandemic. Using regression analyses, we sought to establish whether social background factors (age, gender, education, and political ideology) and concern about scientific integrity predict answers to our Zika-related questions. To explore how beliefs about science and scientists shape individual views, we created two new predictor variables. One represented respondents 


\section{FIGURE 5. DO SCIENTISTS ADJUST THEIR FINDINGS TO GET THE ANSWERS THEY WANT?}

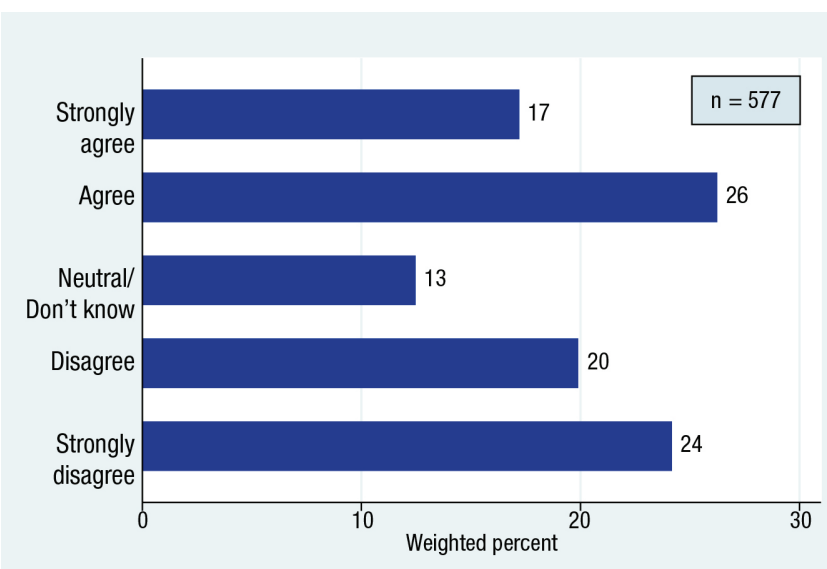

Source: October 2016 Granite State Poll

who agreed that scientists adjust their findings, and the second corresponded to those who trust the CDC as a source of information about the Zika virus.

We found that a number of respondent characteristics correlate to their Zika-related opinions. Answers to our question about support for emergency funding most clearly illustrate how both social background and sciencerelated variables shape views about the Zika virus. Age, education, and political ideology all are significant predictors. Older individuals, those with higher educational attainment, and self-identified liberals were more likely to state that emergency funding for the Zika virus was a high priority. We did not find significant differences in support for Zika funding between men and women (Figure 6).

\section{FIGURE 6. RESPONDENTS SAYING THAT EMERGENCY FUNDING TO COMBAT ZIKA SHOULD BE A HIGH PRIORITY, BY AGE, SEX, LEVEL OF EDUCATION, AND POLITICAL IDEOLOGY}

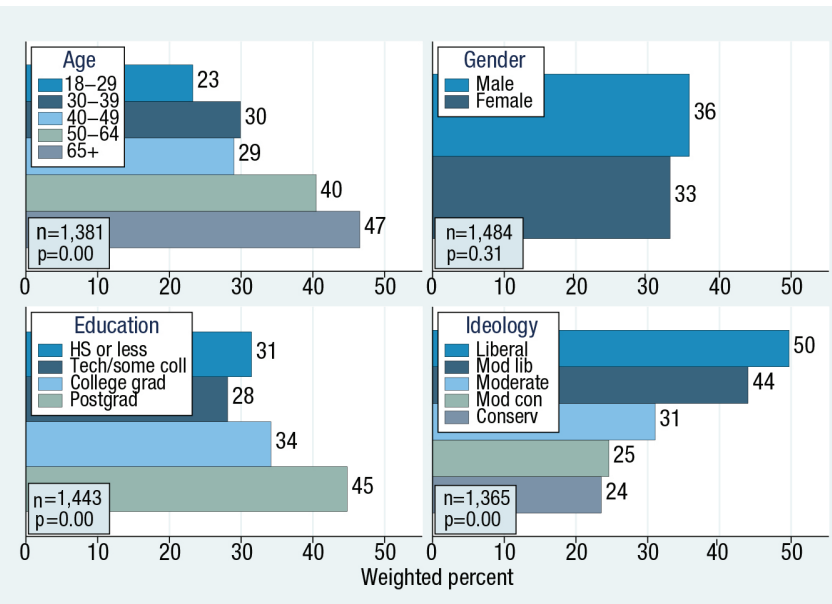

Our results also identified a strong relationship between respondents' views about the integrity of scientists and their belief that emergency funding for Zika is a high priority. Individuals who think scientists adjust their findings were significantly less likely to consider emergency funding for Zika a high priority. We also found that respondents who do not trust the $\mathrm{CDC}$ as a source of information about Zika were less likely to prioritize emergency funding (Figure 7).

\section{FIGURE 7. RESPONDENTS SAYING THAT EMERGENCY FUNDING TO COMBAT ZIKA SHOULD BE A HIGH PRIORITY, BY LEVEL OF TRUST IN THE CDC AND IN SCIENTISTS}

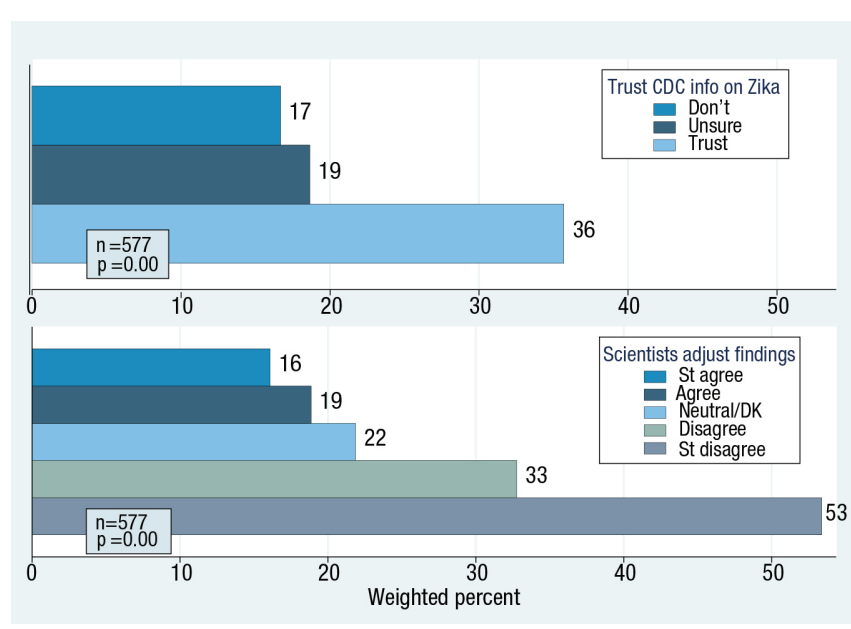

Source: October 2016 Granite State Poll

We also discovered that those individuals who believe scientists adjust their findings are significantly less likely to trust the CDC, believe Zika is a threat to public health, and have confidence in the government's ability to combat the spread of the virus. These additional results illustrate that concern about the integrity of scientists is one of the most important factors shaping views about all aspects of the Zika pandemic.

\section{Discussion: A Cautionary Note for Scientists and Health Officials Combating Zika}

The Zika virus is a global pandemic, yet its implications for public health in the United States remain unclear. Our surveys in New Hampshire found real but limited public concern about the virus at this point. While most individuals support emergency Zika funding and trust the CDC for information, they have clear reservations about the federal government's ability to 
combat the spread of the virus. Individual characteristics that correlate with responses to our Zika questions include age, education, and ideology but not gender, which may be surprising given the virus's link to birth defects. In addition, people's views about the integrity of scientists and their trust in the CDC strongly relate to their beliefs about the threat of the Zika pandemic and the government's response. Controlling an infectious disease like Zika requires an understanding of how it is transmitted and close adherence to guidance from public health officials. Other studies show that Americans are ill informed about both the ways Zika is transmitted and the steps that are needed to combat the spread of the virus. ${ }^{15}$ Those findings along with our results should be a warning to public health officials. The scientific community and public health agencies are key sources of reliable information about Zika. If skepticism about scientists and science-related agencies leads people to ignore public health advisories or look elsewhere for guidance, then the risk of the further spread of the Zika virus and wider health impacts may increase rather than decrease in the future.

These challenges linked to public perceptions of Zika appear to fit into a larger trend involving other science-related topics. Research shows that trust in science, as well as concerns about the integrity of scientists, often correlates with ideology or political outlook across a range of different science-related topics. ${ }^{16}$ The declining trust in science has been tied in part to the scientific community's increasing involvement in contentious social issues that are often considered cultural as much as scientific. ${ }^{17}$ While the science linked to concerns such as climate change and vaccine safety has become politically contested, political or cultural arguments have not yet been salient for Zika. Our findings suggest, however, that individuals' ideological orientation and their general views about scientists already affect perceptions about new and less-polarized concerns, in this case the seriousness of the Zika threat and the need for a public health response. This worrying result should be followed up with additional research and analysis in the future to further illustrate the broad implications of the erosion of trust in science and scientists.

Beyond the apparent politicization of Zika, our study points squarely to a growing public concern about the integrity of scientists and how beliefs about science shape perceptions of all aspects of the Zika pandemic. Public health officials have always faced challenges when communicating health risks, and scientific information has been integral to those efforts. Our findings raise questions about the likely effectiveness of science-based messaging related to the Zika virus in reaching a key portion of the U.S. population that may fundamentally distrust science. There is a need for further investigation of public perceptions of the practice of science and the motivations of scientists. The Zika virus remains a relatively remote health risk for New Hampshire residents. Nonetheless, people's increasing skepticism about scientists, and the way this skepticism appears to erode confidence in agencies like the CDC, may be the real threat to public health. This distrust will likely undermine efforts to combat not only the spread of Zika, but also other infectious diseases and environmental risks that are more immediate dangers to the health and safety of both Granite Staters and the American public in general.

\section{End notes}

1. D. Abramson and R. Piltch-Loeb, U.S. Public's Perception of Zika Risk: Awareness, Knowledge and Receptivity to Public Health Interventions, Briefing Report (New York, NY: New York University, 2016); A. Kirzinger et al., Kaiser Health Tracking Poll: August 2016 (Menlo Park, CA: Kaiser Family Foundation, 2016), http://kff.org/global-health-policy/ poll-finding/kaiser-health-tracking-poll-august-2016/; NORC at the University of Chicago, The Zika Virus: Gaps in Americans' Knowledge and Support for Government Action (Chicago, IL: NORC/March of Dimes, 2016), http://www. norc.org/PDFs/MarchOfDimes/Report_March_of_Dimes_ NORC_Zika_Poll_090616.pdf; STAT and Harvard T.H. Chan School of Public Health, "Zika Virus and the Election Season" (Cambridge, MA: Harvard School of Public Health, 2016), https://cdn1.sph.harvard.edu/wp-content/uploads/ sites/21/2016/08/STAT-Harvard-Poll-August-2016-Zika.pdf.

2. A.S. Fauci and D.M. Morens, "Zika Virus in the Americas-Yet Another Arbovirus Threat," New England Journal of Medicine 374, no. 4 (2016): 601-4.

3. Centers for Disease Control and Prevention (CDC), Zika Virus (Atlanta, GA: CDC, 2017), http://www.cdc.gov/zika/ geo/united-states.html.

4. Ibid.

5. Center for Disease Control and Prevention (CDC), CDC Director: What We're Doing About the Zika Virus (Atlanta, GA: CDC, 2016), https://blogs.cdc.gov/ cdcdirector/2016/02/01/cdc-director-what-were-doingabout-the-zika-virus/. 
6. Ibid; F. Collins, Zika Virus: An Emerging Health Threat (Washington, DC: National Institutes of Health, 2016), https://directorsblog.nih.gov/2016/01/26/zika-virusan-emerging-health-threat/; A.M. Oster et al, "Interim Guidelines for Prevention of Sexual Transmission of Zika Virus-United States," Morbidity and Mortality Weekly Report 65 (2016): 120-21, doi: http://dx.doi.org/10.15585/ mmwr.mm6505e1.

7. Because of the election, the UNH Survey Center conducted two waves of the GSP in October 2016. Data for this study come from both waves of the poll; however, not all questions were asked on the two versions of the GSP.

8. "Do you think that the spread of Zika virus over the next few years will present a major threat, minor threat, or not a threat to public health in the U.S.?"

9. "As a source of information about the Zika virus, would you say that you trust, don't trust, or are unsure about science agencies such as the Centers for Disease Control (CDC) that study infectious diseases?"

10. "How confident are you in the federal government's ability to respond effectively to an outbreak of Zika virus in the United States - very confident, somewhat confident, not so confident, or not confident at all?"

11. Collins 2016; A. Kodjak, Congress Ends Spat, Agrees to Fund \$1.1 Billion to Combat Zika, National Public Radio, Sept. 28, 2016, http://www.npr.org/sections/healthshots/2016/09/28/495806979/congress-ends-spat-over-zikafunding-approves-1-1-billion.

12. "President Obama [or the Director of the U.S. Centers for Disease Control (CDC)] has asked Congress for emergency funds to combat Zika virus. Do you think that providing Zika funds should be a high priority, medium priority, low priority, or not a priority at all for the current Congress?" This question was included on both waves of the October 2016 GSP, thus there were a larger number of respondents than for our other questions. In addition, one version of the question stated that President Obama was requesting this funding and the other that the $\mathrm{CDC}$ was making this request. We did not find any significant differences, or interactions with political outlook, between the responses to these two alternative versions of the question.
13. L.C. Hamilton, "Conservative and Liberal Views of Science: Does Trust Depend on Topic?" (Durham, NH: Carsey School of Public Policy, 2015), http://scholars.unh. edu/carsey/252/.

14. "Do you agree or disagree that scientists adjust their findings to get the answers they want? If agree or disagree: Is that strongly or just somewhat?"

15. Abramson and Piltch-Loeb 2016; Kirzinger et al. 2016; NORC 2016; A.E. Shartzer et al., Women of Reproductive Age Lack Knowledge of Zika Virus Transmission and Effects (Washington, DC: Urban Institute, 2016), http://www. urban.org/sites/default/files/publication/84811/2000958women-of-reproductive-age-lack-knowledge-of-zika-virustransmission-and-effects.pdf.

16. Hamilton 2015; L.C. Hamilton, J. Hartter, and K. Saito, “Trust in Scientists on Climate Change and Vaccines," Sage Open (2015), doi: 10.1177/2158244015602752.

17. G. Gauchat, "Politicization of Science in the Public Sphere: A Study of Public Trust in the United States, 1974 to 2010," American Sociological Review 77, no. 2 (2012): 167-87.

\section{About the Authors}

Thomas G. Safford is associate professor of sociology and faculty fellow at the Carsey School of Public Policy (https://carsey.unh.edu/person/thomas-safford).

Lawrence C. Hamilton is professor of sociology and senior fellow at the Carsey School of Public Policy at the University of New Hampshire (https://carsey.unh. edu/person/lawrence-hamilton).

Emily H. Whitmore is a graduate student in the department of sociology at the University of New Hampshire.

\section{A c know ledg ment s}

Support for this study came from the College of Liberal Arts and the Research Office at the University of New Hampshire. The authors would like to thank Michael Ettlinger, Curt Grimm, Michele Dillon, Amy Sterndale, Laurel Lloyd, and Bianca Nicolosi at the Carsey School of Public Policy for their contributions.

\title{
TH University of New Hampshire Carsey School of Public Policy
}

The Carsey School of Public Policy at the University of New Hampshire is nationally recognized for its research, policy education, and engagement. The school takes on the pressing issues of the twenty-first century, striving for innovative, responsive, and equitable solutions.

\author{
Huddleston Hall • 73 Main Street • Durham, NH 03824 \\ (603) $862-2821$ \\ TTY UsERS: DIAL 7-1-1 OR 1-800-735-2964 (RELAY N.H.) \\ carsey.unh.edu
}

